
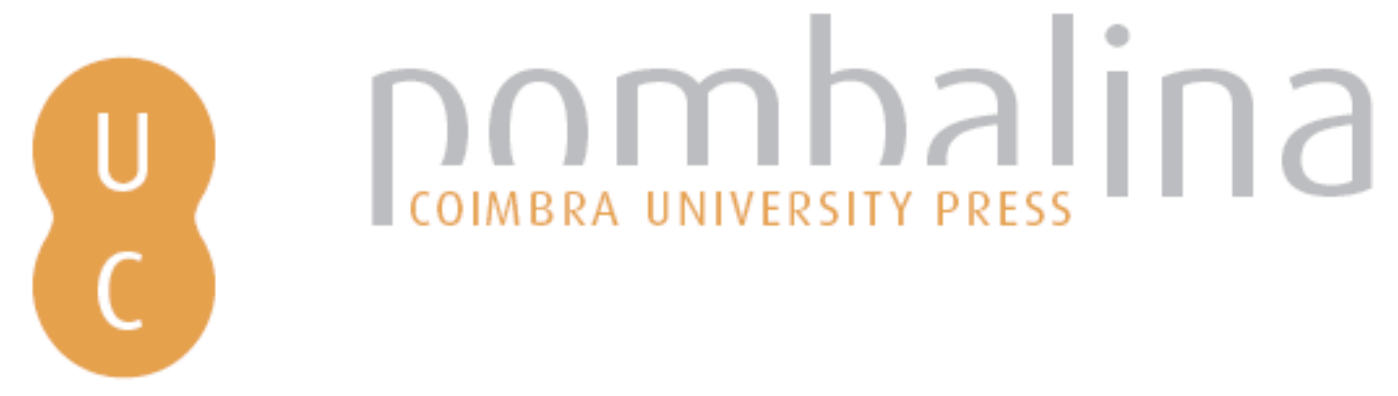

As perspetivas e os desafios da sucessão de Estados no Século XXI

Autor(es): $\quad$ Santos, Gabriela Barrionuevo Bertochi dos

Publicado por: Imprensa da Universidade de Coimbra

URL

persistente: URI:http://hdl.handle.net/10316.2/47435

DOI: $\quad$ DOI:https://doi.org/10.14195/978-989-26-1524-0_11

Accessed : $\quad$ 26-Apr-2023 14:21:06

A navegação consulta e descarregamento dos títulos inseridos nas Bibliotecas Digitais UC Digitalis, UC Pombalina e UC Impactum, pressupõem a aceitação plena e sem reservas dos Termos e Condições de Uso destas Bibliotecas Digitais, disponíveis em https://digitalis.uc.pt/pt-pt/termos.

Conforme exposto nos referidos Termos e Condições de Uso, o descarregamento de títulos de acesso restrito requer uma licença válida de autorização devendo o utilizador aceder ao(s) documento(s) a partir de um endereço de IP da instituição detentora da supramencionada licença.

Ao utilizador é apenas permitido o descarregamento para uso pessoal, pelo que o emprego do(s) título(s) descarregado(s) para outro fim, designadamente comercial, carece de autorização do respetivo autor ou editor da obra.

Na medida em que todas as obras da UC Digitalis se encontram protegidas pelo Código do Direito de Autor e Direitos Conexos e demais legislação aplicável, toda a cópia, parcial ou total, deste documento, nos casos em que é legalmente admitida, deverá conter ou fazer-se acompanhar por este aviso.

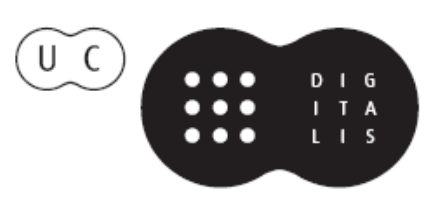


JOSÉ MANUEL PUREZA JOSÉ JUSTE RUIZ (COORDS.)
IMPRENSA DA

UNIVERSIDADE

DE COIMBRA

COIMBRA

UNIVERSITY

PRESS
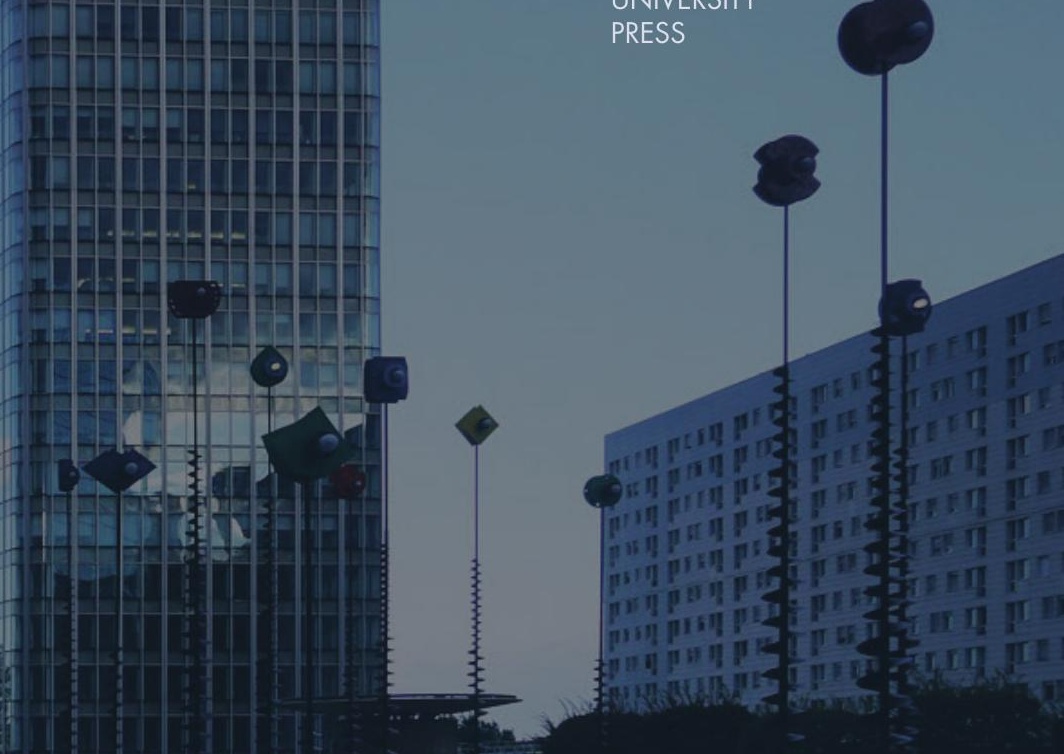

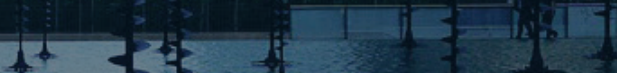

OS ESTADOS

EA ORDEM

INTERNACIONAL

CONTEMPORANEA

ATAS DO V ENCONTRO LUSO-ESPANHOL DE Professores de Direito internacional e RELAÇÕES INTERNACIONAIS 


\section{AS PERSPETIVAS E OS DESAFIOS DA SUCESSÃO DE ESTADOS NO SÉCULO XXI}

\section{Gabriela Barrionuevo Bertochi dos Santos}

\section{Introdução - um breve histórico}

Haja vista que o Estado "não é produto de mera elaboração jurídica convencional: ele é antes de tudo uma realidade física, um contingente humano estabelecido em determinada área territorial, sob a regência de uma ordem jurídica” (Rezek, 2011: 335), é possível afirmar que o caráter de perpetuação de um Estado encontra respaldo no princípio da continuidade de seus elementos materiais constitutivos, que asseguram a preservação do ente, ainda que em colapso o seu sistema de poder vigente ou no caso de ocorrência de modificações expressivas na determinação da titularidade de sua soberania.

Nessa toada, tem-se que a sucessão de Estados significa, nos termos das Convenções de Viena de 1978 e 1983, a substituição de um Estado (predecessor) por outro (sucessor) na responsabilidade pelas relações internacionais de determinado território.

A relevância do referido instituto não é recente, tanto que Grocius, já em 1625, sobre ele refletia, delineando regras baseadas no direito civil romano.

A fim de melhor compreender tal relevância sob a perspectiva histórica mais recente, considera-se que três grandes momentos ao longo do século XX marcaram a evolução das reflexões acerca da 
sucessão de Estados: o primeiro referente ao fim da Primeira Grande Guerra, o segundo, referente ao término da Segunda Grande Guerra e a posterior descolonização e, por fim, o terceiro, referente às secessões ocorridas a partir da Queda do Muro de Berlim, em 1989, e o fim da União das Repúblicas Socialistas Soviéticas (URSS), em 1991.

O fim da Primeira Guerra Mundial e o consequente desaparecimento dos grandes impérios multinacionais, como o russo, o otomano e o austro-húngaro, e a tentativa de redefinir a Europa e suas fronteiras, marcou o começo de uma nova fase na compreensão do conceito de Estado, traduzido na perspectiva de uma "Europa das nacionalidades", que aliava indissociável e complementarmente as ideias de Estado e nação.

A tentativa da União Soviética de se escusar das dívidas contraídas sob a vigência do antigo regime czarista, amparada em uma suposta descaracterização do princípio da continuidade em razão da ruptura política então verificada, pode ser considerada o primeiro grande exemplo de desobediência explícita as normas de Direito Internacional. Contudo, não há de se falar em escolhas sem consequências, daí a imposição de uma situação de isolamento internacional à URSS até a celebração de uma solução negociada. O mesmo vai acontecer, posteriormente, no tocante às consequências da descolonização.

Entre 1945 e 1960, já no pós Segunda Guerra Mundial, verificou-se um novo período de modificações na sistemática internacional, com o surgimento de, aproximadamente, uma centena de novos Estados e a sua identificação e admissão progressivas como sujeitos de Direito Internacional e membros da Organização das Nações Unidas (ONU).

A ampliação do número de Estados no pós-guerra não se restringiu apenas ao panorama europeu, estendendo-se, principalmente, à África e ao Pacífico, "onde o Princípio da Autodeterminação, tal como consagrado na Carta das Nações Unidas, passou a ser invocado visando à independência da quase-totalidade dos territórios 
dependentes, como as antigas colônias e os territórios sob tutela" (Accioly e Silva, 2000: 93).

No tocante ao processo de descolonização, duas correntes doutrinárias distintas foram propostas quando da delimitação das consequências advindas da sucessão de Estados: de um lado, a ideia da tabula rasa ou clean slate, a qual defendia que todo e qualquer vínculo assumido pela antiga metrópole deveria ser ignorado, não possuindo nenhum impacto ou relevância em relação ao novo Estado; e de outro, a pretensão da sucessão universal, que postulava que o novo sujeito de Direito Internacional estaria obrigado a dar prosseguimento a todos os vínculos previamente acordados pela metrópole, independentemente de sua destinação.

Segundo Casella (2007: 1158), a grande lição que pode ser extraída do período de descolonização "é, justamente, que nenhuma das duas posições extremas pode prevalecer". Na resolução de uma boa parte dos casos, adotou-se uma posição intermediária, de sucessão modulada, em que foram ponderados o posicionamento e os interesses dos Estados recém-independentes, bem como a natureza das obrigações já contraídas, resultando na boa construção e aplicação do Direito Internacional ${ }^{1}$.

Após o fim do período da descolonização, havia quem afirmasse que o instituto da sucessão de estados estaria fadado ao esquecimento, uma vez que sua função precípua já havia sido exaustivamente exercida. Porém, não foi bem esse o quadro constatado. Em 1978, foi negociada a primeira Convenção de Viena sobre Sucessão de Estados, a versar sobre as implicações do instituto em matéria de tratados, e em 1983, a segunda Convenção, discorrendo sobre

1 O único caso de transição, sem qualquer vínculo programado de Direito Internacional, foi a independência do Congo, porque o tratado entre o Congo e a Bélgica, de 1960, nunca chegou a entrar em vigor. Não por acaso, terá sido essa, justamente, transição das mais complexas e problemáticas do período, com efeitos prolongados. (Casella, 2007: 1158). 
a sucessão de Estados em matéria de bens, arquivos e dívidas. Contudo, o resultado prático advindo do processo de negociação dos referidos instrumentos e o pouco impacto por eles alcançado refletiu a desmotivação dos Estados em regulamentar e dispor sobre um tema tido como ultrapassado, o qual não mais seria necessário.

Os anos 90, contudo, trouxeram à baila uma nova perspectiva de aplicação do referido instituto, consubstanciada na criação de 26 novos Estados, sendo o último, Montenegro, no ano de 2006. Nessa nova fase de sucessão de Estados, é possível relacionar alguns processos de aglutinação, como a unificação da Alemanha e a do Iêmen, mas, sobretudo, três divisões singulares, detentoras de "particularidades no seu tratamento e nas suas consequências para os Estados diretamente interessados e para o conjunto da comunidade internacional" (Casella, 2007:1159).

A primeira delas se deu entre a República Tcheca e a Eslováquia, com a dissolução da então Tchecoslováquia e a constituição de duas novas repúblicas, integrantes da ONU desde 1993 e da União Europeia, desde 2004. "Alguns autores dizem que a Tchecoslováquia seria o exemplo de 'divórcio perfeito', pois foi planejado segundo o Direito e houve estrita proporcionalidade na divisão de dívidas e patrimônio" (Casella, 2007:1159), levando-se em consideração critérios de densidade populacional - resultando, assim, em 2/3 para a República Tcheca e 1/3 para a Eslováquia.

No caso da URSS, a sucessão de Estados apresentou-se mais complexa, a começar pela designação da Federação Russa como o legítimo Estado sucessor na maioria das organizações internacionais, chegando a ocupar, inclusive, a posição de membro permanente no Conselho de Segurança da ONU - detentora do poder de veto - e a condição de potência nuclear. Além disso, tem-se a incansável luta por parte dos três Estados bálticos - a Estônia, a Letônia e a Lituânia - para retomar a sua soberania do ponto em que foi interrompida, em 1940, com a invasão soviética. 
No entender de Casella (2007: 1159), no que tange aos três Estados bálticos, não há de se falar em novos Estados e sim em um "resgate de sua condição soberana", uma vez que, em razão de violação às normas de Direito Internacional cometida pela URSS no ato da invasão, eles foram forçadamente impedidos de a exercerem na condição de sujeitos de Direito Internacional.

Enquanto a Federação Russa sucedeu a URSS na maioria das organizações internacionais e os três bálticos se colocaram numa posição de restabelecimento de antigos valores, as demais repúblicas soviéticas tiveram transições particulares. A Ucrânia e a Belarus conseguiram resgatar a sua condição de membros da ONU sem a necessidade de apresentar novas candidaturas, ainda que não a detivessem, anteriormente, de fato. As demais repúblicas foram submetidas ao modelo de transição da Comunidade de Estados Independentes, regulamentado pelas Atas de Alma Ata e de Minsk, ambas de 1991.

Temos, ainda, a penosa dissolução da antiga República Socialista Federativa da Iugoslávia, marcada por sucessivos períodos de guerra civil e de supressão dos direitos humanos, envolvendo a Eslovênia, a Croácia, a Bósnia-Herzegovina e o Kosovo, este último já em 1999.

Como exceção à regra, em 2006, verifica-se o último fenômeno sucessório envolvendo a antiga Iugoslávia: a secessão de Montenegro do então Estado Federal da Sérvia e Montenegro - constituído em 2003. Dessa vez, a criação do novo Estado foi efetivada de forma pacífica e organizada, mediante referendum favorável à independência.

\section{As convenções das Nações Unidas sobre a sucessão de Estados}

A questão da sucessão de Estados "foi incluída na primeira agenda da Comissão de Direito Internacional da ONU (CDI), mas não como assunto prioritário" (Accioly e Silva, 2000: 93 e 94). Posteriormente, 
a convite da própria Assembleia Geral, a CDI iniciou um estudo mais aprofundado sobre o tema, para o qual foram indicados como relatores os renomados juristas, Humphrey Waldock, para analisar a sucessão em matéria de tratados, e Mohammed Bedjaoui, para analisar a sucessão em matéria de bens, arquivos e dívidas de Estado.

Embora os problemas relativos à sucessão de Estados sejam de alto nível de complexidade, os dois instrumentos jurídicos resultantes do referido estudo e que culminaram nas duas Convenções de Viena sobre Sucessão de Estados, em 1978 e em 1983, tinham como objetivo precípuo consolidar bases de Direito Internacional positivo, através das quais seriam estabelecidas regras genéricas capazes de solucionar eventuais questões supervenientes.

Diversos entendimentos acerca, em especial, das consequências oriundas do fenômeno sucessório foram apresentados quando da elaboração das referidas Convenções, a começar com a corrente privatista, que embasava suas ideias nas propostas de Grocius. Nesse caso, defendia-se que as soluções para os problemas sucessórios encontravam-se no direito romano, isto é, de que, analogamente às regras de direito civil, a aceitação de uma herança implicaria também a de seu ônus.

Para uma segunda corrente, "a utilização de regras de direito privado deveria ser evitada, recorrendo-se ao direito público. Na prática, os resultados são bastante semelhantes" (Accioly e Silva, 2000: 94).

A corrente majoritária rejeita a noção de substituição de um Estado por outro na responsabilidade pelos direitos e obrigações ligados à extinção do antigo Estado, isto é, a sucessão trata de soberania sobre o território. Entende-se que os direitos e obrigações do Estado sucessor lhe são concedidos pelo Direito Internacional no ato de sua constituição, de modo que com a extinção do Estado predecessor ocorre uma tabula rasa (clean slate). Essa regra, entretanto, não é absoluta, uma vez que admite exceções no tocante às delimitações fronteiriças e ao reconhecimento dos direitos adquiridos e da equidade. 
A prática, contudo, vislumbra uma análise mais pormenorizada e específica das variadas hipóteses de sucessão, levando em consideração os problemas então colocados, como os relativos aos tratados, aos bens, aos arquivos, às dívidas, à legislação, à nacionalidade, às consequências da formação do novo Estado e a sua situação face às organizações internacionais. Esta foi a orientação adotada por ambas as Convenções de Viena sobre Sucessão de Estados.

É válido ressaltar que as referidas Convenções reconheceram cinco expressões principais do instituto sucessório, a partir das quais estabeleceram suas considerações, a saber:

a) a sucessão relativa a uma parte do território, mediante transferência e preservação da personalidade dos dois Estados predecessores;

b) o surgimento de um Estado de recente independência (newly independent State);

c) a união de Estados;

d) a separação de parte ou de partes de um Estado, com a consequente formação de um novo; e

e) a dissolução do Estado.

Enquanto base de Direito Internacional codificado, pode-se afirmar que as regras da Convenção das Nações Unidas sobre sucessão de Estados em matéria de tratados, de 1978, foram relativamente aceitas pela comunidade internacional, uma vez que, somente em 1996, alcançou o número suficiente de ratificações para a sua entrada em vigor - tendo como suportes substanciais os novos países da Europa Central. Por sua vez, o mesmo não pode ser dito quanto à Convenção das Nações Unidas sobre a sucessão de Estados em matéria de bens, arquivos e dividas de Estado, concluída em 1983, já que, ainda hoje, apenas sete, de um mínimo de quinze países, ratificaram-na. A sua entrada em vigor, portanto, encontra-se comprometida indefinidamente. 
Ademais, constatou-se uma grande relutância, em ambas as Convenções, em admitir a existência de direitos específicos para os Estados recém-independentes. Aliás, em vários casos, "existia um argumento forte contra a ênfase dada a eles, ou seja, de que os territórios que poderiam eventualmente tornar-se independentes eram poucos e que as Convenções [...] previam que as suas regras só se aplicariam às situações criadas depois de sua entrada em vigor" (Accioly e Silva, 2000: 95).

De qualquer modo, cumpre admitir que nenhuma dessas duas Convenções alcançou grande relevância na prática. Como exemplo, podemos citar a decisão da Corte Internacional de Justiça no caso Gabcikovo-Nagymaros, em 1997, em que, ao aplicar o disposto na Convenção, entendeu que esta não havia inovado no campo normativo em questão e sim apenas o reproduzido, mediante a positivação do Direito Internacional consuetudinário.

Para Casella (2007: 1162), "este é o paradoxo a se levar em conta" quando se trata do desenvolvimento da codificação desde o fim da Segunda Guerra Mundial, uma vez que outras convenções, também oriundas do trabalho da CDI, "tornaram-se sinônimo do Direito Internacional vigente", mostrando-se, portanto, praticamente inquestionáveis. Esse é o entendimento, por exemplo, quanto às Convenções de Viena de 1961 (relações diplomáticas), de 1963 (relações consulares) e de 1969 (direito dos tratados), e a Convenção das Nações Unidas sobre o Direito do Mar, de 1982, que inovou ao abarcar dentre as suas realizações um grande número de Estados signatários, a abrangência e especificidade do tema e a criação de um sistema de solução de controvérsias próprio - o Tribunal Internacional para o Direito do Mar.

Esse panorama convencional em que se enquadra o fenômeno sucessório apresenta-se como escolha política e definição de critérios, mas não representou, efetivamente, grande feito enquanto obra de codificação do Direito Internacional. 


\section{Regime jurídico da sucessão de Estados: normas aplicáveis}

De acordo com o Direito Internacional consuetudinário, no que tange ao fenômeno sucessório, é comum que as principais consequências advindas da sucessão - o futuro dos tratados celebrados, as questões relativas à dívida pública e às obrigações financeiras, a determinação da nacionalidade das pessoas afetadas, os problemas ligados à legislação interna, o destino dos bem públicos e a situação frente às organizações internacionais - sejam definidas por lei do Estado unificado ou por tratado entre as soberanias resultantes do desmembramento ou nele envolvidas.

Nesse sentido, vale dizer que, para que se obtenha um resultado efetivamente palpável e condizente com a realidade, deve-se recorrer a uma análise casuística da matéria em tela. Buscar-se-á, portanto, aliar tal análise às regras costumeiras em direito das gentes já codificadas, para ponderar considerações de caráter universal passíveis de aplicação às modalidades sucessórias já mencionadas.

\subsection{Os tratados e as obrigações financeiras}

Já preconizava Guggenheim (apud Accioly e Silva, 2000: 95) que, em Direito Internacional, "o problema da sucessão de Estados verifica-se, sobretudo, no campo do direito convencional, mormente no caso de existir acordo anterior".

O fato de existir mais de uma convenção internacional destinada a externar soluções a esse respeito, nomeadamente a Convenção de Viena de 1969 e a Convenção de Viena de 1978, tornou a questão menos controvertida, especialmente porque ambas se ocupam dos tratados multilaterais, sobre os quais pouco havia sido delimitado antes da Segunda Guerra Mundial. 
No que concerne aos tratados fronteiriços, fixou-se a sua manutenção ipsis litteris. Nos termos do artigo 13 da Convenção de Viena de 1978, "uma sucessão de Estado não afeta as fronteiras estabelecidas por tratado, tampouco as obrigações e os direitos estabelecidos em tratado relativo ao regime vigente na zona fronteiriça". Já nos chamados "tratados sobre direitos reais", a sua manutenção é condicionada à expressa anuência do outro Estadoparte, que confirmará a vigência de um tratado de navegação ou servidão, por exemplo, na hipótese de as relações entre os dois Estados manterem-se amistosas.

No caso das demais obrigações convencionais e dos débitos de uma maneira geral, tem-se que, na agregação, o Estado resultante é o responsável por assumir o conjunto das obrigações e dos débitos de seus integrantes; enquanto, tanto no desmembramento quanto na transferência territorial, a máxima adotada é a da repartição ponderada da dívida. Assim, não é impossível que o novo Estado seja responsabilizado pela integralidade de uma dívida contraída pelo Estado predecessor, quando assim feito em prol da parte do território que veio a tornar-se independente.

Ainda na hipótese de desmembramento, há dívidas, contudo, cuja origem foi um investimento centralizado e político dos montantes emprestados do exterior. Neste caso, a doutrina estabelece uma distinção entre dívidas de Estado, que são aquelas "contraídas no interesse geral da comunidade e por isto próprias para serem compartilhadas na hora da sucessão”, e dívidas de regime, que são “contraídas no interesse do esquema de poder preexistente e muitas vezes para sustentar a campanha colonial” (Rezek, 2011: 340). Ao novo Estado não é atribuída qualquer responsabilidade para com as dívidas de regime ${ }^{2}$.

2 "Alguns juristas (como Louter) entendem até mesmo que as dívidas contraídas pelo Estado anexado, em virtude da luta travada com o Estado anexador para a 
Sob essa perspectiva, entende-se que o newly independent State possui o benefício da tabula rasa, mormente quanto aos tratados bilaterais celebrados pelo Estado primitivo e, segundo o entendimento consagrado pelo artigo 16 da Convenção de 1978, também no caso dos tratados multilaterais. No tocante aos últimos, tem-se que o novo Estado tem a faculdade de aderir ao então pactuado, mediante o envio de uma notificação de sucessão ao depositário - caso esta seja compatível com os limites de abertura do tratado em questão ${ }^{3}$.

\subsection{A nacionalidade da população}

Segundo a doutrina tradicional, a nacionalidade do Estado anexador se impõe à população do Estado anexado, no caso de anexação total, ou aos habitantes do território em relação ao qual se verificou a anexação, na hipótese de anexação parcial; restando àqueles contrários à nova relação nacional vigente, a emigração. Nos casos de separação, divisão ou desmembramento de Estado, entende-se que a nacionalidade dos novos Estados deve ser estendida aos nacionais do anterior, desde que neles residam. E na agregação, defende-se que, frente à criação de uma nova personalidade jurídica internacional, devem-se extinguir as nacionalidades próprias de cada Estado agregado em benefício de uma nacionalidade comum.

Por outro lado, a doutrina moderna e a nova orientação internacional direcionam-se no sentido de automaticamente aplicar a nacionalidade do Estado anexador à população do Estado

garantia de sua própria independência, devem ser transferidas ao Estado em favor do qual se fez a anexação. O certo é que, na prática - explica Accioly - o Estado sucessor frequentemente repele tais dívidas qualificando-as como odiosas (odious debts)". (Mazzuoli, 2011: 482).

3 Fenômeno conhecido como oscilação dos tratados ou Princípio da Mobilidade das Fronteiras nos Tratados. 
anexado (anexação total) ou da parte do território anexada (anexação parcial), mas resguardando o seu direito de opção, isto é, a faculdade do indivíduo de manter a sua nacionalidade originária ou de adotar a nacionalidade do Estado anexador. Outra modalidade de determinação da nacionalidade dos habitantes do novo Estado é o sistema de plebiscito popular, que se contrapõe à opção individualizada.

No entender de Mazzuoli (2011), infelizmente não é possível verificar, por hora, uma norma costumeira precisa a respeito dessa questão. Mesmo o previsto pelo art. 15 , $\S \S 1^{\circ}$ e $2^{\circ}$, da Declaração Universal dos Direitos Humanos de $1948^{4}$, não atinge tal propósito, já que não define claramente a quem se destina a norma e em qual situação ela se aplica.

\subsection{A legislação interna adotada}

No tocante à legislação interna vigente após a ocorrência do fenômeno sucessório, tem-se que, no caso de anexações - total ou parcial -, o Estado ou área territorial anexado passa a reger-se pelas leis vigentes no Estado incorporador; devendo ser respeitados os direitos previamente adquiridos.

Quando há separação de Estados, cada novo Estado reger-se-á por um ordenamento jurídico próprio escolhido livremente. Mazzuoli (2011) atenta para o fato de que, tanto no caso de anexação quanto de cessão voluntária, as obrigações e as responsabilidades do Estado sucedido que foram contraídas sob a égide da legislação anterior são extintas, isso em razão de seu caráter de pessoalidade.

4 ONU. Declaração Universal dos Direito Humanos de 1948. Consultada a 10.11.2014 em: < http://www.dudh.org.br/declaracao/>. Artigo 15, $\S \S 1^{\circ}$ e $2^{\circ}$. In verbis: "1. Toda pessoa tem direito a uma nacionalidade. 2 . Ninguém será arbitrariamente privado de sua nacionalidade, nem do direito de mudar de nacionalidade". 


\subsection{O domínio do Estado: bens públicos e particulares}

No quesito referente à propriedade de bens públicos, verifica-se que, em situações de anexação - total ou parcial - ou de fusão, todos os bens destinados ao uso comum do povo, como as ruas, as estradas e os parques, os de uso especial, como os prédios públicos utilizados pela administração, e ainda os dominiais, são transferidos necessariamente para o Estado detentor da soberania territorial, em função de serem indissociáveis do território. Já quanto às áreas de propriedade privada, a solução não é pacífica, visto que parte da doutrina defende que o "Estado sucessor tem sobre o território o chamado domínio eminente, que é atributo da soberania e vale para toda a sua extensão (mesmo as áreas de propriedade privada)" (Rezek, 2011: 338); e outra, que apenas é possível operar a transferência mediante prévia indenização.

Em caso de separação ou desmembramento de Estado, a regra é que os novos Estados permaneçam titulares dos bens públicos e privados que se encontrem na parte do território sucedido que lhes é devida. Contudo, alerta Rezek (2011: 339) que, em problemas referentes a certos créditos e valores mobiliários, bem como a bens imóveis que o primitivo Estado possuía no exterior - como aqueles destinados ao abrigo das missões diplomáticas e consulares -, o "critério topográfico" não se mostra como solução adequada. No desmembramento da União Soviética, a Rússia acabou por assumir, aparentemente de forma consensual, todo o patrimônio que abrigara a diplomacia soviética; porém, na bipartição da República Árabe Unida, um incidente foi proposto para determinar quem seria o novo proprietário do prédio que acolhia o antigo corpo diplomático republicano no Rio de Janeiro, Brasil.

No tocante aos arquivos públicos, entende-se que a questão apenas pode gerar alguma controvérsia nas hipóteses de secessão 
ou desmembramento. Segundo a doutrina clássica, há dois tipos de arquivos estatais: os de gestão e os de soberania - ou políticos -, sendo que somente os primeiros devem ser transferidos para o novo Estado. A Convenção de Viena de 1983 limita-se a determinar a entrega de todos os arquivos que digam respeito ao Estado sucessor por parte do Estado primitivo, sem estipular qualquer compensação material ou discriminação quanto à espécie de arquivo a ser entregue.

\subsection{A participação em organizações internacionais}

No que tange à sucessão do novo Estado em organizações internacionais nas quais era membro o Estado sucedido, a regra é a da não sucessão. Nesse sentido, o Estado sucessor deve requerer à organização internacional de seu interesse uma autorização de ingresso, nos termos dispostos pelos atos constitutivos da respectiva organização. O Conselho da Europa, frente ao pleito das Repúblicas Tcheca e Eslovaca em ocuparem automaticamente o lugar da antiga Tchecoslováquia na União Europeia, entendeu que a sucessão era incabível e que um novo processo admissional deveria ser instaurado. Para Mazzuoli (2011: 484), esse também deveria ter sido o posicionamento adotado pela ONU ao analisar pedido correlato, contudo, não foi bem isso que se verificou quando das sucessões da Rússia à ex-URSS e da República Tcheca e da República Eslovaca à Tchecoslováquia, deferidas sem qualquer autorização expressa da Carta das Nações Unidas - instrumento que regulamenta a admissão de novos membros.

Vale lembrar que, em organizações internacionais de tipo fechado ou restrito, a sucessão de Estados pode restar impossível, assim como nas hipóteses de organização de integração ou de aliança política. 


\section{Estudo de caso: a eventual independência da Escócia e as suas consequências}

No dia 18 de setembro de 2014, os escoceses votaram em um referendo que simbolizou um grande marco na vida política do Reino Unido desde 1707, quando foi formalizada, através da celebração dos Acts of Union, a união dos Reinos da Inglaterra e da Escócia já governados pelo mesmo monarca desde 1603.

A discussão em torno do tema advém, mais intensamente, de meados de 2012, quando o governo central do Reino Unido - sediado em Londres -, consentiu com a realização de uma consulta popular quanto à manutenção ou não da união, proposta esta feita pelo governo local escocês. O principal defensor da independência da Escócia era o Partido Nacional Escocês (Scottish National Party), que constitui a maioria no parlamento local desde as últimas eleições, em 2011; e os principais opositores eram os Partidos Conservador, Trabalhista e Liberal Democrático (Conservative Party, Labour Party e Liberal Democrats), todos ingleses. A campanha em favor da continuidade do Reino Unido chamava-se Better Together e a em favor da secessão, Yes Scotland.

No tocante às intenções de voto, pouca variação foi sentida nas pesquisas de opinião desde 2012, uma vez que os simpatizantes à manutenção da união mantiveram-se em vantagem considerável. Vislumbrando, então, melhor esclarecer os seus pontos de vista e propiciar aos eleitores da Escócia uma maior conscientização acerca da relevância da questão, tanto o governo britânico, em 20125, quanto o governo escocês, em $2013^{6}$, publicaram relatórios oficiais. O inglês, de autoria dos professores James Crawford - Universidade

\footnotetext{
${ }^{5}$ Scotland analysis: Devolution and the implications of Scottish independence. 2012.

${ }^{6}$ Scotland's future: your guide to an independent Scotland. 2013.
} 
de Cambridge - e Alan Boyle - Universidade de Edimburgo -, e o escocês, de múltipla autoria.

Sob essa perspectiva, cumpre explorar os principais eixos do debate, de modo a apresentar os dois lados da moeda, isto é, os prós e os contras da União e da independência trazidos por esses dois documentos. Portanto, ao subsumir o caso concreto à teoria, mister é retomar os conceitos de continuidade e sucessão de Estados. Quando há continuidade do Estado, indubitável é a titularidade referente aos direitos e às obrigações deste, uma vez que, tratando-se do mesmo Estado, aquela não se altera. Na sucessão, contudo, tal assertiva não é verdadeira. Por isso, buscar-se-á analisar as possíveis consequências da eventual independência escocesa sob o prisma inicial da continuidade do Reino Unido, para depois avançar para o da sucessão.

Crawford e Boyle, em seu relatório, trazem à baila a configuração de três possíveis cenários no caso de uma eventual independência escocesa, quais sejam: o de que um dos novos Estados permaneceria titular da personalidade jurídica do atual Reino Unido, enquanto o outro figuraria como Estado inteiramente novo; o de que a personalidade jurídica do antigo Reino Unido seria extinta, constituindo-se Estados completamente novos; e o de que a Inglaterra deteria a personalidade do então Reino Unido, enquanto a Escócia retornaria ao seu estatuto anterior, de 1707.

Ressalvando-se, é claro, que a precisão acerca dos eventuais rumos que seriam tomados para consolidar a independência escocesa somente poderia ser alcançada após a análise do conjunto de negociações que, em caso de resultado positivo, seria engendrado, bem como do futuro reconhecimento internacional, os referidos juristas concluíram que a primeira hipótese, com o surgimento da Escócia como novo Estado e a permanência do restante do Reino Unido em seu status quo ante, seria, sem dúvidas, a mais provável. Esse é o posicionamento usualmente adotado na prática. 
Ademais, como reforço a esta previsão, tem-se um precedente histórico de influência direta à questão da independência da Escócia: a criação do Estado Livre Irlandês - situação fática similar à proposta aos eleitores escoceses. Nesse caso, entendeu-se que mesmo que o Reino Unido tenha perdido parte de seu território original, a sua personalidade jurídica seria mantida tal qual era antes da secessão irlandesa, figurando a "nova Irlanda" como novo sujeito de Direito Internacional.

É válido ressaltar, ainda, que o relatório escocês não abarca, numa perspectiva estritamente jurídica, a possibilidade da continuidade da personalidade jurídica do Reino Unido, de modo que, nas únicas oportunidades em que invoca tal matéria, recorre ao comportamento adotado pelo Reino Unido frente ao desmembramento da antiga Tchecoslováquia e ignora uma análise casuística da situação - como a improvável aceitação, por parte do governo britânico, de perder a sua personalidade jurídica e o fato de que ao restante do Reino Unido pertenceria a maior parte do território, a população e os recursos.

No que tange à participação da Escócia na União Europeia (UE), o relatório escocês sustenta que uma vez que a Escócia já integra o referido bloco de integração, não há de se falar em submissão à nova candidatura. Entretanto, de acordo com pronunciamento público feito pela própria cúpula europeia, é certo que as pretensões escocesas de permanecer automaticamente na União Europeia são equivocadas. Uma vez independente, a Escócia deveria sim pleitear, como qualquer outro Estado candidato, a sua admissão como membro da União. Outra possibilidade seria solicitar ao novo Reino Unido que interviesse a seu favor, através da via instituída pelo artigo 48 do Tratado da União Europeia, em prol de uma modificação nos tratados para que a Escócia pudesse permanecer na UE nas condições pretendidas.

Outra questão interessante que se põe a esse respeito referir-se-ia ao futuro do "Reino Unido remanescente" na União Europeia, visto 
que, sem os votos escoceses - tradicionalmente mais europeístas do que a média britânica -, instalar-se-ia um cenário nebuloso quanto a sua permanência na UE, quando da realização, em 2015, do referendum anunciado pelo primeiro ministro David Cameron. "Não seria descartável um cenário, dentro de alguns anos, da Escócia dentro da UE e o Reino Unido fora" (Guimón, 2014).

No que diz respeito à participação de uma Escócia independente em outras organizações internacionais, como a ONU, tem-se como formalmente necessário o envio da solicitação de adesão. Porém, tendo em vista experiências anteriores recentes, como o ingresso do Sudão do Sul em 2011, nota-se uma maleabilidade por parte das Nações Unidas ao facilitar o ingresso de novos Estados logo após adquirir a sua independência. Tudo indica, todavia, que a Escócia não sucederia o antigo Reino Unido na condição de membro permanente do Conselho de Segurança da ONU e detentor do poder de veto. O natural seria que o novo Reino Unido assumisse tal condição, nos moldes do precedente russo.

Quanto à Organização do Tratado do Atlântico Norte (OTAN), o governo escocês assegurou que, logo que adquirida a independência, iria pronunciar formalmente a sua intenção de integrá-la mediante os procedimentos convencionais. Contudo, tal candidatura poderia vir a ser comprometida, em razão de sua manifesta intenção de retirar da Escócia a base dos submarinos nucleares Trident.

Sobre essa polêmica situação, o atual governo escocês se comprometeu que tiraria a base da Escócia. O governo britânico, em contrapartida, respondeu que "se o resultado do referendo significar uma ameaça à situação atual seriam consideradas outras opções, mas qualquer solução alternativa teria um custo enorme" (Guimón, 2014). Posto isto, caberia tão só aguardar futuras negociações para que um consenso sobre a transferência da base fosse alcançado. No que toca aos demais arsenais bélicos, cogitava-se a possibilidade de serem divididos em função da sua localização geográfica. 
Segundo o governo escocês, vislumbrava-se que, em dez anos contados da independência, a Escócia detivesse seu próprio aparato militar, com exército, marinha e aeronáutica, composto por 15.000 efetivos regulares e 5.000 reservistas. Atualmente, há, em território escocês, 14.510 funcionários do Ministério de Defesa do Reino Unido - 7,5\% do total -, os quais, segundo proposta do relatório escocês, deveriam ter a faculdade de optar entre permanecer a serviço das forças armadas do Reino Unido remanescente ou se incorporar às da Escócia. "Londres adverte de que não se trata de algo tão simples como recrutar as unidades baseadas em Escócia, as quais 'são parte essencial do Exército britânico e que, isoladas, não constituiriam uma força coerente, crível e equilibrada'” (Guimón, 2014).

Outro ponto de crucial interesse caso a Escócia se tornasse independente, foi qual moeda seria adotada pelo novo Estado. Em princípio, a Escócia teria três possibilidades, a saber: a libra esterlina, o euro ou uma nova moeda própria. $\mathrm{O}$ discurso independentista sempre foi uníssono e constante ao afirmar que a nova Escócia permaneceria usando a libra, através do estabelecimento de uma união monetária com o Reino Unido remanescente. No entanto, os três partidos britânicos de oposição e o próprio presidente do Banco da Inglaterra negaram tal possibilidade, haja vista o restante do Reino Unido não querer se tornar responsável, por exemplo, pelo resgate de bancos escoceses em caso de crise financeira.

Além disso, uma eventual dependência da Escócia à política monetária do Banco da Inglaterra tornaria a sua moeda muito vulnerável, já que o país estaria limitado a intervir nessa matéria, possuiria sérias restrições quanto a manipular sua política fiscal e não teria à sua disposição muitos recursos para assegurar a estabilidade financeira, algo temeroso para uma economia sustentada pelo petróleo. Ademais, Krugman (apud Guimón, 2014) já advertira que "a combinação de independência política e moeda compartilhada é uma receita para o desastre”. A única certeza que se tinha a esse 
respeito era que, em caso de votação favorável, a libra permaneceria como a moeda oficial escocesa até a finalização das negociações com o Reino Unido.

A adoção do euro como moeda nacional era uma opção ainda mais delicada, visto que dependeria do ingresso da Escócia na UE e, sobretudo, da vontade da população em superar o sentimento de rejeição para com a referida moeda ${ }^{7}$. Daí advém outra polêmica: a recusa escocesa em aderir obrigatoriamente ao euro, caso fosse admitida à UE (art. 119, Tratado de Funcionamento da União Europeia). Os independentistas defendiam a prerrogativa da Escócia em não aceitar o euro, recorrendo ao exemplo da Suécia, que, apesar de ser sujeita a tal obrigação, nunca abandonou a sua moeda; e do próprio Reino Unido, que ao aderir à União, estabeleceu $o p$ ting out quanto a adentrar na zona do euro. Contudo, no estágio atual de integração, tal prerrogativa é praticamente inexistente, de modo que se a Escócia anunciasse a sua intenção de condicionar a sua entrada à recusa do euro, seguramente as suas chances de ser admitida reduzir-se-iam drasticamente.

A última opção, referente à criação de uma nova moeda, também é afastada pelo governo escocês. Dentre as possíveis dificuldades impostas incluir-se-iam "o aumento de custos de transação na economia (especialmente com o restante do Reino Unido, principal parceiro comercial da Escócia e destino de 2/3 de suas exportações), a reduzida credibilidade inicial do novo banco central escocês (e consequente aumento dos custos de empréstimos), além de problemas relativos à flutuação da taxa de câmbio" (Kamiyama, 2014: Parte III).

No que tange à dívida pública do antigo Reino Unido, o natural seria a sua repartição ponderada, com base em critérios de densida-

${ }^{7}$ Ver: Kamiyama, Marcel, "O referendo de independência escocês e o Direito Internacional - Parte III", Núcleo de Estudos Internacionais. Consultada a 14.11.2014 em http://neiarcadas.wordpress.com/2014/03/13/refesciii/. 
de populacional. Contudo, a Escócia poderia reivindicar o desconto do valor dos dividendos gerados pelo petróleo proveniente de suas águas territoriais no montante correspondente a sua parte da dívida. O governo britânico, que garantiu permanecer como fiador de toda a dívida existente, a fim de não comprometer a credibilidade do Reino Unido no mercado financeiro internacional; poderia alegar, em contrapartida, "que o gasto público per capita na Escócia é entre $10 \%$ e 15\% maior do que no resto do Reino Unido" (Guimón, 2014).

Nesse sentido, tem-se, ainda, as dúvidas acerca da partilha dos recursos energéticos do Mar do Norte, fonte essencial de renda para uma Escócia independente. Dois parâmetros poderiam ser adotados: o primeiro, que respeitaria as delimitações da plataforma continental e obedeceria a máxima da linha média, nos termos da Convenção das Nações Unidas sobre o Direito do Mar; ou o segundo, que dividiria tais recursos de acordo com a proporção populacional de cada Estado.

$\mathrm{Na}$ primeira hipótese, "a porcentagem do recurso que seria mantida pela Escócia dependeria de qual Estado teria jurisdição sobre as Northern Isles (Orkney e Shetland), que poderão ser objeto de disputa por terem se tornado parte da Escócia e do Reino Unido" (Kamiyama, 2014: Parte III) apenas no final do século XV. Já na segunda, o Reino Unido remanescente permaneceria com praticamente $90 \%$ (noventa por cento) dos referidos recursos. Sob essa perspectiva, seria inequívoca a realização de negociações para definir qual o critério mais conveniente para ambos os Estados.

$\mathrm{Na}$ análise da questão da nacionalidade e do livre trânsito entre a Escócia independente e o novo Reino Unido, os nacionalistas escoceses asseguravam que, mesmo que a separação determinasse a existência de uma nacionalidade escocesa distinta da britânica, não seria necessário o uso de passaportes e o controle de fronteiras para transitar entre os dois Estados. Porém, tal entendimento não é pacífico.

Com o baixo índice de natalidade e a alta taxa de envelhecimento da população, a Escócia se vê ultimada a aumentar o número de 
trabalhadores. Para isso, os nacionalistas escoceses prometem adotar uma política de incentivo à imigração, no caso de independência. No entanto, o Reino Unido caminha em direção oposta, uma vez que não parece disposto a modificar suas políticas migratórias, crescendo cada vez mais a xenofobia no país, retratada com a eleição do Partido da Independência do Reino Unido (UKIP) para o Parlamento Europeu, com o maior número de votos a nível nacional. Adotando posicionamentos tão distintos no tocante à imigração, revelar-se-ia difícil que os controles fronteiriços entre Escócia e Reino Unido fossem inexistentes.

Por outro lado, mesmo já tendo declarado a sua intenção de integrar a Escócia à União Europeia, o Partido Nacional Escocês (SNP):

parece mais partidário de permanecer na Common Travel Area (zona de livre trânsito entre o Reino Unido e a República da Irlanda) do que de aderir ao Tratado de Schengen (que prevê a livre circulação em países da Europa continental), e isso poderia ser um problema na hora de bater à porta de Bruxelas (GUIMÓN, 2014).

Por fim, cumpre salientar a vontade clara trazida no relatório escocês de que a Rainha da Inglaterra continuaria a ser a chefe de Estado da Escócia independente, assim como acontece no Canadá, na Austrália e na Nova Zelândia. Tal posição apresentava uma única ressalva: a de que o monarca inglês apenas continuaria a ocupar tal cargo, enquanto o povo escocês continuasse desejando que o país adotasse o regime monárquico. A Rainha, por sua vez, tentou manter-se imparcial, embora em breve discurso, ter levemente se inclinado a não apoiar a secessão.

\section{Conclusão}

A transformação e a extinção de Estados originam uma série de questões concernentes ao fenômeno sucessório, gerando especial interesse para o Direito Internacional Público, eis que indissociáveis 
aos direitos e às obrigações contraídos pelo Estado que se extingue e que, a partir de então, passarão, ou não, para o novo Estado.

Assim, o instituto da sucessão de Estados pode ser definido como a substituição de um Estado por outro, relativamente aos seus direitos e deveres. O que se visa, portanto, com o seu estudo, é aferir qual o limite da referida substituição e até que ponto o "domínio de validade da ordem jurídica de um Estado se transfere a outro" (Mazzuoli, 2011: 478), em razão de uma alteração na titularidade ou na condição da personalidade jurídica do primeiro.

Verifica-se, então, a sucessão de Estados quando um Estado (predecessor) é substituído por outro (sucessor) no tocante ao domínio de seu território, ou de parte dele, e às responsabilidades pelas suas relações internacionais. A sucessão pode ocorrer de maneira forçada, de modo que um dos Estados envolvidos é totalmente absorvido pelo outro; voluntária, caracterizada quando a união tem por objetivo precípuo a constituição de um novo Estado; através de cessão de parte do território de um Estado para outro; ou, ainda, mediante desmembramento de Estados.

Ante tais modalidades sucessórias tão distintas, suas inúmeras consequências e, sobretudo, as particularidades de cada caso, procurou-se estabelecer certas normas internacionais gerais a fim de guiar os Estados na resolução das controvérsias em que, nesta seara, estejam envolvidos. Assim, celebraram-se as Convenções de Viena sobre Sucessão de Estados, em 1978 e 1983. Infelizmente, a adesão da comunidade internacional aos seus corolários não foi muito expressiva, isso em função de uma falsa crença de que se tratava de um tema já ultrapassado.

Contudo, já dizia o ditame popular que "o mundo dá voltas". Um problema até então tido como sanado, surge com grande força em pleno Século XXI. As questões fronteiriças, que desde o final do Século XX encontravam-se relativamente adormecidas, renascem com a intensificação dos movimentos separatistas "intraestatais" e 
mostram-se mais flexíveis, no que toca à abertura negocial apresentada por alguns Estados. Este foi o caso do Reino Unido frente à insurgência separatista escocesa.

Daí, numa tentativa de subsumir a teoria ao caso concreto e contextualizar a importância da sucessão de Estados atualmente, buscou-se analisar quais as possíveis consequências de uma eventual independência da Escócia, no caso de o referendo ter tido um resultado positivo.

É possível concluir, portanto, que se o resultado da consulta popular escocesa tivesse autorizado a independência da Escócia com a sua consequente remodelação interna e externa, provavelmente estaríamos, agora, diante de uma situação sucessória sui generis sob a perspectiva internacional. Para além dos problemas tradicionalmente postos em fenômenos sucessórios - como a nacionalidade da população, o domínio dos bens públicos e arquivos, a sucessão em matéria de tratados e outros -, configurar-se-iam incertezas mais profundas, envolvendo blocos de integração econômica de natureza parafederal, comprometimentos econômicos delicados em razão da baixa absorção de novas moedas fortes no mercado financeiro global e o estremecimento da identidade histórico-cultural dos povos frente às divergentes políticas migratórias.

Não há de se falar, então, em caráter arcaico da sucessão de Estados e sim de sua imperiosa investigação, de modo a consolidar as concepções tradicionais e inovar em prol do desenvolvimento de novos instrumentos de solução de controvérsias sucessórias, delineando quais as perspectivas acerca do alcance do instituto, bem como quais desafios devem ser enfrentados para se obter uma maior eficácia frente a relações muito mais complexas e globalizadas que outrora.

\section{Referências}

Accioly, Hildebrando; Silva, G. E. do Nascimento (2000), Manual de Direito Internacional Público. São Paulo: Saraiva. [14 ${ }^{\mathrm{a}}$ ed] 
Boyle, Catherine (2014), "Scottish Independence Would Have Broad Impact on U.K. Economy", NBC News, Scotland Independence Vote's Storyline. Consultada a 14.11.2014, em: <http://www.nbcnews.com/storyline/scotland-independencevote/scottish-independence-would-have-broad-impact-u-k-economy-n198976>.

Casella, Paulo Borba (2007), "Sucessão de Estado no Direito Internacional Pósmoderno", Revista da Faculdade de Direito da Universidade de São Paulo, 102, 1155 - 1170.

Escócia (2013), "Scotland's future: your guide to an independent Scotland". Consultado a 12.11.2014, em: <http://scotgov.publishingthefuture.info/publication/scotlandsfuture $>$.

Guimón, Pablo (2014), "Dez perguntas e respostas sobre uma Escócia independente", El País - Edição Brasil, Caderno Internacional. Consultado a 14.11.2014 em: < http://brasil.elpais.com/brasil/2014/09/17/internacional/1410951044_430192. html>.

Kamiyama, Marcel (2014), "O referendo de independência escocês e o Direito Internacional - Parte I, II e III", Núcleo de Estudos Internacionais. Consultada a 14.11.2014 em: < http://neiarcadas.wordpress.com/2014/02/19/refesci/>.

Mazzuoli, Valério de Oliveira (2011), Curso de Direito Internacional Público. São Paulo: Editora Revista dos Tribunais. [5 ${ }^{\mathrm{a}}$ ed]

Reino Unido (2012), "Scotland analysis: Devolution and the implications of Scottish independence". Consultada a 12.11.2014 em: <https://www.gov.uk/government/ uploads/system/uploads/attachment_data/file/79417/Scotland_analysis_Devolution_ and_the_implications_of_Scottish_Independan...____.pdf $>$.

Rezek, José Francisco (2011), Direito Internacional Público: curso elementar. São Paulo: Saraiva. [13 ${ }^{a}$ ed]

Russell, Meg (2014), "Constitutional consequences of Scottish referendum will be complex and profound: a yes vote would have meant a lot of work but the outcome puts the West Lothian question centre stage", The Guardian, The Observer. Consultada a 14.11.2014 em: <http://www.theguardian.com/politics/2014/sep/21/ constitutional-consequences-referendum-west-lothian-question>.

Stern, Brigitte (1998), Dissolution, Continuation and Succession in Eastern Europe. Haia: Kluwer Law International.

Tharoor, Ishaan; Taylor, Adam (2014), "9 big questions before Scotland's big vote on independence", The Washington Post, WorldViews. Consultada a 14.11.2014 em: < http://www.washingtonpost.com/blogs/worldviews/wp/2014/09/17/9-bigquestions-before-scotlands-big-vote-on-independence/>.

Volkhonsky, Boris (2014), "Separação da Escócia da Inglaterra pode ser comparável ao desmembramento da URSS", Rádio Voz da Rússia, Moscou. Consultada a 14.11.2014 em: < http://portuguese.ruvr.ru/news/2014_09_13/Separa-o-da-Esccia-da-Inglaterra-pode-ser-compar-vel-ao-desmembramento-da-URSS-2847/ > .

Waibel, Michael (2013), "Boyle and Crawford on Scottish Independence", Blog of the European Journal of International Law. Consultada a 13.11.2014 em: < http:// www.ejiltalk.org/boyle-and-crawford-on-scottish-independence/>. 